\title{
People in the News
}

Beth J. Dodd and Margo Gutierrez won 2001 Librarian Excellence Awards from the University of Texas-Austin. The awards carry a $\$ 1,000$ stipend. Dodd has served as curator of the Alexander Architectural Archive in the Architecture and Planning Library since 1995. Colleagues identify her as one who has made a difference in the growth of the collection and in the high level of services that users have come to expect. Gutierrez heads the Mexican American Library Program in the Nettie Lee Benson Latin American Collection. As a bibliographer for Mexican American and Latino Studies materials, she has been instrumental in acquiring important archival collections for the Benson Collection.

Rita Gibson, access services technician at the State Law Library of Montana in Helena, Montana, and Sue Mahmoodi, continuing education and library research specialist for the Minnesota state library agency, have won $L i$ brary Mosaics and the Council on Library/ Media Technicians 2001 award for outstanding support staff and outstanding supporter of support staff, respectively.

\section{Appointments}

Keith C. Cottam, dean of libraries at the University of Wyoming since 1983, has accepted the position of associate dean and director of the University of Wyoming Casper College (UW/CC) Center. During Cottam's tenure, the UW Libraries collection doubled to more than 1.2 million, with additional holdings of 1 million government documents and 2.8 million microforms. He led the installation of the first automated public access library catalog in 1985 and the migration to

Ed. note: To ensure that your personnel news is considered for publication, write to Ann-Christe Young, production editor, C\&RL News, 50 E. Huron St., Chicago, IL 60611-2795; e-mail: ayoung@ala.org; fax: (312) $280-2520$.
Voyager last year. Cottam is active in the Wyoming Library Association, serving as president (1998-99). He is also involved with ALA, particularly with the Committee on Accreditation and the accreditation of graduate library education.

David Gansz is now director of the Watson Library at Wilmington College in Wilmington, Ohio. From 1993 to 1995 , Gansz served as director of the library at Naropa University in Boulder, Colorado, and from 1995 to 1998 he was a senior research librarian in the Electronic Database Department at Bell \& Howell Information and Learning, Inc. For the past three years, he has been head of the reference department at the Rockbridge Regional Library in Lexington, Virginia. $\mathrm{He}$ is a member of Beta Phi Mu. Gansz published a book of poetry in 2000, Millennial Scriptions: The Asben Book of Logres, and has been nominated for literary awards by the poetry Center of San Francisco State University and the Library of Virginia's Center for the Book.

Lorraine J. Haricombe has been named dean of libraries and learning resources at Bowling Green State University. She has served as associate dean for the public service division of the Northern Illinois University (NIU) Libraries since 1998. The prior six years she was head of the circulation department at NIU and was involved in library and statewide initiatives to prepare libraries for emerging changes in the profession, including initiatives to serve regional distance-education centers. From 1975 to 1986, Haricombe was library director at Pennisula Technikon in the Republic of South Africa. A member of several professional organizations, including ALA and ACRL, she has written for several publication and co-edited the book Creating the Agile Library for a Changing Environment, published by Greenwood Press in 1998 .

Priscilla Anderson has been named conservator for Harvard University's Weissman Preservation Center. 
Matt Blessing has been appointed head of the special collections and university archives at Marquette University Libraries.

Randall Bowman is now reference/instruction librarian at Elon University in Elon, North Carolina.

Martha Brantigan-Stowell is the new senior cataloger in the Germanic Division at the Harvard College Library.

Kevin Butterfield is now head of technical services in the law library at the University of Illinois at Urbana-Champaign.

David Buxton is now campus librarian at Cooperative Academic Library Services at the Washington State University, Spokane campus.

Paul Callister has been appointed law reference librarian at the University of Illinois at Urbana-Champaign.

Cristina Campell has been appointed Melvyl Union Catalog Implementation project manager for the California Digital Library.

Timothy Cole is now mathematics librarian at the University of Illinois at UrbanaChampaign.

Karen Coyle has been appointed Melvyl Union Catalog Database and Technology team lead for the California Digital Library.

Richard Ellis has been named head of the St. John's College Library at the University of Manitoba.

José-Marie Griffiths has been named the first holder of the Doreen E. Boyce chair in Library and Information Science in the School of Information Sciences at the University of Pittsburgh.

Eugene Hainer has been named as director of library development at the Colorado State Library.

Leigh Haynes is now programmer/analyst at the University of California-Berkeley.

Paul Healey is the new head of public services in the law library at the University of Illinois at Urbana-Champaign.

Peter Hook has been appointed law reference librarian at the University of Illinois at Urbana-Champaign.

Jennifer Jacobs is the new university archivist at the University of CaliforniaIrvine.

Ann Jensen is now Melvyl Union Catalog Implementation services team lead for the California Digital Library.
Rachel Kaczor has been appointed cataloger of the Photo Access Project in the Schlesinger Library at Harvard University's Radcliffe Institute for Advanced Study.

Michelle LaVoie has been named assistant librarian in the health sciences library at the University at Buffalo, SUNY.

Georgina Lewis has been appointed head of the Father Harold Drake Library at the University of Manitoba.

Craig Likness is now head of archives and special collections at the University of Miami's Otto G. Richter Library.

Rob Melton is now literature/humanities bibliographer of the Geisel Library at the University of California-San Diego.

Ellen Meltzer is now senior associate for Education, Usability, and Outreach for the California Digital Library.

Barbara Mitchell has been appointed head of public services in the Frances Loeb Library at Harvard University.

Ophelia Morey has joined the University at Buffalo, SUNY, as an assistant librarian in the health sciences library.

Michael Morin has been appointed senior assistant librarian in the University $\mathrm{Li}^{-}$ braries at the University of Buffalo.

Andy Morton is now head of access and delivery services at the University of Richmond.

Christopher Prom is now assistant university archivist at the University of Illinois at Urbana-Champaign.

Greg Raschke has been appointed head of the Spahr Engineering Library at the University of Kansas.

Alix Reiskind is the new assistant visual resources librarian in the Frances Loeb Library at the Harvard Design School.

David Rios has been appointed assistant university librarian for the sciences at the University of California-Riverside.

Harry Samuels has joined Endeavor Information Systems as the digital library projects coordinator.

Steve Scheuler has been appointed reference librarian at Valdosta State University in Valdosta, Georgia.

Lisa Scott has been appointed social sciences librarian at the University of Richmond.

Heather Smith has been named reference librarian and diversity intern program coordinator at Oberlin College.

Mary Sullivan has joined the Emerson 
College staff as coordinator for outreach and reference librarian.

Edward H. Teague has been appointed head of the Architecture and Allied Arts Library at the University of Oregon.

Melissa D. Trevvett has been named vice president and director of programs and services at the Center for Research Libraries in Chicago.

Heather Tunender has been appointed electronic reference services librarian at the University of California-Irvine.

Lara Ursin is now science librarian and reference coordinator in the Owen Science and Engineering Library at Washington State University.

Mary Van Winkle has been appointed serials librarian in the Baker Library at Harvard Business School.

Paul C. Vermouth is now English bibliographer for the Social Sciences in the Widener Library at Harvard College Library.

David Ward has been appointed assistant undergraduate librarian for reference services at the University of Illinois at UrbanaChampaign.

Beth Warner is now director of Digital Library initiatives at the University of Kansas.

Mame Warren has been named project coordinator of academic publishing at the

\section{Advertiser index}

$\begin{array}{lr}\text { ACM } & 636 \\ \text { ACRL } & 633,634 \\ \text { ALA/CIPA } & 629 \\ \text { American Chemical Society } & 584\end{array}$

American Psychological

Association Cover 4, 622

American Theological Library

Association $\quad 580$

CHOICE 641

EBSCO 607

Endeavor Information Systems 608

Faxon/Rowecom Cover 3

Gale Group $\quad 601$

H. W. Wilson 642

IEEE $\quad 645$

infoUSA 619

Johns Hopkins University Press 628

netLibrary Cover 2, 577

OCLC 595

Probalt AB $\quad 606$

Swets Blackwell $\quad 602$
Milton S. Eisenhower Library in Johns Hopkins University.

Daisy P. Waters has been appointed assistant librarian in the Central Technical Services unit of the University Libraries at the University at Buffalo, SUNY.

Keith Weimer is now government information librarian at the University of Richmond.

Thomas Weissinger is now Afro-Americana Studies librarian at the University of Illinois at Urbana-Champaign.

Steven Wise has joined Our Lady of the Lake University as a reference librarian.

Eric M. Wolf is now assistant cataloger for the Frick Art Reference Library in New York, New York.

Suzanne Wones is now reference librarian in the John F. Kennedy School of Government Library at Harvard University.

Geetha Yapa is the new science reference librarian at the University of Califomia-Riverside.

Lihong Zhu has been appointed cataloging librarian at Washington State University.

\section{Retirements}

Wilma Geil is now music special collections coordinator and associate professor emerita at the University of Illinois at UrbanaChampaign.

Louise Leonard has retired after more than 20 years as Middle East and Africana cataloger at the George A. Smathers Library of the University of Florida in Gainesville.

Patrick J. Russell Jr., rare book cataloger, has retired after 26 years at the Brancroft Library at the University of California (CU)Berkeley. Prior to his position at Berkeley, Russell worked as a rare book cataloger at Washington University Libraries in St. Louis. At CU, Russell helped develop the special online bibliographical access that became a part of the GLADIS online catalog. He worked on special projects, such as cataloguing the rare books of William Randolph Hearst and the records of the Tebtunis papyrus manuscripts - acquired by the university from an archaeological expedition sponsored 1899 by Phoebe Apperson Hearst. Russell served on 
the ACRL's RBMS Standards Committee. His work on the committee involved the development of specialized thesauri for use in rare book and manuscript libraries.

Beth Stafford, Women's Studies librarian, has retired from the University of Illinois at Urbana-Champaign.

\section{Deaths}

Ben C. Bowman, 88, retired librarian, died February 1, 2001. He began his library career at the Newberry Library, where he spent 16 years. His other positions included director of libraries at the University of Vermont, librarian at Hunter College in New York City, and director of libraries at the University of Rochester, from which he retired in 1976. He then spent three years at Johns Hopkins University, in the rare books and special collections department, before completely leaving the profession.

Christine Blucher Germino, bibliographer and reference librarian in the Central Library at Vanderbilt University, died April 10,2001 , after a brief illness. Germino began work in the library in 1983 as a library assistant in the circulation department of the Central Library and became a bibliographer in 1990. She specialized in German language and literature and comparative literature. She also served as co-coordinator of instruction in the Central Library.

Wham Kum, 73, retired chairman of the Department of Librarianship at Turkey's Hacettepe University in Ankara, died on January 3, 2001. Kum distinguished himself as a medical librarian, as a university administrator-for a time he was Hacettepe's secretary general, the institution's chief operating officer-and as a library educator. While attending the University Kentucky, Kum worked in the university library's circulation department and was later employed by the Science and Industry branch of the Brooklyn Public Library. Kum was founding director of the medical library at Hacettepe and went on to establish the university's Institute of Librarianship and Documentation.
Lawrence Clark Powell, 94, UCLA's second university librarian, died March 14, 2001, in Tucson. Powell began his career at UCLA in 1938 as a junior assistant in the library's acquisition department. He became university librarian and director of the William Andrews Clark Memorial Library in 1944 and directed the UCLA Library over the next 17 years. During his tenure, the library's holdings grew from 400,000 volumes to 1.5 million volumes. in 1959, toward the end of his tenure as university librarian, Powell led the effort to create the School of Library Service, which later became the Graduate School of Library and Information Science. Powell retired from UCLA in 1966 and had the Powell Library Building named for him. He moved to Tucson in 1971 and served as a consultant to the University of Arizona on library projects. Among his many books are California Classics: The Creative Literature of the Golden State (1971) and The Manuscripts of D. H. Lawrence (1937). He also wrote numerous articles on literary, historical, and bibliographic topics for scholarly and general-interest periodicals. He was a life member of ALA.

Joyce M. Watson, 65 , building planning coordinator for the University of Hawaici at Manoa Library, died March 14, 2001. She coordinated the library's planning program during the design and construction of the second (1970-79) and third (1990-01) additions to Hamilton Library. As the only librarian in Hawaii qualified in this specialty, Watson was well known not only on campus, but also among architects and contractors in the com-

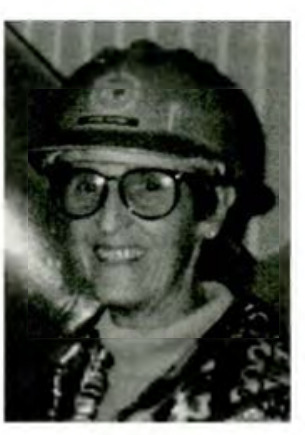

Joyce Watson munity for her energetic involvement and ability to communicate the complex, changing nature of the library's needs and operations. In the academic library world, she contributed her practical solutions to library pest management in tropical environments. She was also a leading horticulturist. Her panax collection is the most complete in Hawaii and will be the basis for the memorial garden at Hom'omaluhia Botanical Garden outside Honolulu. 